\title{
Identifikasi Reaktor Brusellosis Pada Sapi di Rumah Potong Hewan (RPH) Kota Ambon
}

\section{Identification of brucellosis reactor in Cattle at the City Abattoir in Ambon}

\author{
Astri Dwyanti Tagueha* \\ Program Studi Peternakan, Fakultas Pertanian, Universitas Pattimura \\ *acitunpatti@gmail.com
}

\begin{abstract}
Diterima : 03 Agustus 2020
Disetujui : 29 Agustus 2020

Diterbitkan : 31 Agustus 2020
\end{abstract}

\begin{abstract}
Abstrak : Brusellosis merupakan penyakit ekonomis pada hewan yang bersifat infeksius dan mudah menyebar. Evaluasi keberadaan reaktor di titik penyebaran seperti RPH penting untuk dilakukan. Penelitian ini bertujuan untuk mengetahui prevalensi reaktor brusellosis pada sapi di RPH Kota Ambon. Variabel yang diamati yaitu asal sapi, umur, jenis kelamin, dan status kebuntingan. Besaran sampel ditentukan berdasarkan rumus deteksi penyakit dengan tingkat konfidensi 95\%, asumsi prevalensi 2\%, dan simpangan baku 0,05. Sebanyak 175 sampel darah diambil untuk pemeriksaan Rose Bengal Test (RBT). Data dianalisis secara deskriptif. Hasil penelitian menunjukkan bahwa 10.29\% sapi yang dipotong di RPH terindikasi sebagai reactor brusellosis. Ditinjau dari daerah asal sapi, sebanyak 5,71\% sapi reactor berasal dari Pulau Seram dan 4,57\% berasal dari Pulau Buru. Hasil ini perlu divalidasi dengan Complement Fixation Test (CFT) sehingga dapat dipakai sebagai bahan pertimbangan dalam merumuskan program monitoring dan survailans secara berkelanjutan.
\end{abstract}

Kata Kunci : Ambon, brusellosis, reaktor, RPH, sapi

\begin{abstract}
Brucellosis is an economical, infectious, and contagious disease in animals. Evaluation of brucellosis reactor existence at entry point such as abattoir is fundamentally important. The objective of this study was to investigate the prevalence of reactor in cattle slaughtered at an City Abattoir in Ambon. Some variable observed in the present study were origin region of cattle, age, sex, and pregnancy status. Number of blood samples were determined using by a detect disease formula with $95 \%$ confidence level, $2 \%$ for prevalence assumption, and error 0.05. A total of 175 cattle blood samples were collected to identify the brucellosis reactor based on Rose Bengal Test (RBT). The descriptive analysis was applied to describe the variables, The result demonstrated that $10.29 \%$ cattle slaughtered at the city abattoir in Ambon were detected as brucellosis reactor. In term of the origin region of the slaughtered cattle, $5.71 \%$ and $4.57 \%$ cattle were imported from Seram and Buru Islands, respectively. These findings need to be validated by Complement Fixation Test (CFT) before being used as a guidance for sustainability of monitoring and surveillance programs for Brucellosis in livestock.
\end{abstract}

Keywords : abattoir, ambon, brucellosis, cattle, reactor

\section{Pendahuluan}

Berkenaan dengan kontribusi sub sektor peternakan dalam upaya mencapai tujuan pembangunan berkelanjutan (sustainable development goals - SDG) maka seluruh faktor penghambat termasuk terganggunya kesehatan ternak perlu diantisipasi. Hal ini penting dilakukan mengingat sumbangsih usaha peternakan berkaitan langsung dengan tujuan SDG diantaranya untuk memerangi kemiskinan dan menjamin kesehatan penyetaraan gender, dan pertumbuhan ekonomi [1] Keberadaan brusellosis, penyakit bakterial kontagius dan zoonosis mengancam populasi ternak dan perekonomian rumah tangga peternak sehingga perlu diwaspadai [2]

Infeksi brusellosis pada sapi dilaporkan mengakibatkan kerugian ekonomis yang signifikan dan ditaksir mencapai $\mathbf{1 , 8 \%}$ dari nilai total asset ternak di Indonesia atau sekitar Rp 3,5 trilyun per tahun [3]. Perhitungan tersebut bersumber dari aspek kualitas (meningkatnya resiko infertilitas, panjangnya selang beranak, kegagalan konsepsi, dan resiko carier) dan kuantitas (penurunan bobot badan dan produksi susu dan mati/lemahnya anak pedet). Kedua dampak infeksi tersebut mengarah pada penurunan populasi sapi $[4,5]$. 
Infeksi brusellosis di Provinsi Maluku pertama kali dilaporkan pada tahun 1982 yang terjadi didua kecamatan $[6,7]$. Penyebaran bruselosis semakin meluas dan telah mengintroduksi 3 gugus pulau, yaitu Pulau Seram, Pulau Buru, dan Pulau Leti $[8,9]$. Siklus penularan yang terjadi secara terus menerus dari tahun ke tahun mengindikasikan bahwa manajemen kesehatan tidak diterapkan dengan baik, cakupan program vaksinasi tidak menyeluruh, serta lalu lintas ternak tidak dapat dikendalikan.

Survei dan monitoring bruselosis perlu rutin dijadwalkan karena penyakit ini bersifat infeksius dan mudah menyebar. Titik penyebaran bruselosis seperti pelabuhan dan rumah potong hewan (RPH) merupakan lokasi pengambilan sampel yang strategis. Studi di Makasar menyebutkan bahwa 8,33\% sapi di RPH Tamangapa terdeteksi sebagai reaktor sedangkan observasi di RPH Oeba Kupang menemukan $57 \%$ sapi sebagai reaktor [10, 11]. Data ini menunjukkan pentingnya evaluasi status reaktor brusellosis di RPH apalagi didukung fakta bahwa tingginya tingkat penularan pada tukang jagal mencapai $10 \%$ [12] dibanding pekerja dan pemilik ternak, yaitu 5,8\% [13].

RPH Kota Ambon merupakan satu-satunya fasilitas resmi pemerintah yang setiap harinya melayani permintaan pemotongan sapi rata-rata 417 ekor per bulan [14]. Umumnya sapi yang dipotong di RPH Kota Ambon berasal dari Pulau Seram dan Pulau Buru yang dilaporkan memiliki prevalensi bruselosis $>2 \%$. Hasil identifikasi reaktor brusellosis di RPH Kota Ambon secara tidak langsung menggambarkan status infeksi di daerah asalnya. Dengan demikian penting untuk mempunyai data prevalensi reaktor brusellosis di tingkat RPH Kota Ambon.

\section{Materi dan Metode}

\subsection{Tempat dan Waktu}

Penelitian ini telah berlangsung pada bulan Mei - Juni 2019. Pengambilan sampel darah dilakukan setiap hari di RPH Kota Ambon sedangkan pengujian RBT terlaksana di Laboratorium Veteriner dan Kesehatan Ternak Jurusan Peternakan, Universitas Pattimura.

\subsection{Alat dan Bahan}

Peralatan yang digunakan terdiri dari vacutainer plain, holder dan jarum venoject, sarung tangan, plate porselin, tusuk gigi, pipet $10 \mu \mathrm{l}$, stopwatch, sentrifus, Eppendrof, dan kotak pendingin. Bahan yang dipakai, yaitu serum darah sapi, antigen Brucella produksi PUSVETMA, alkohol 70\%, ice pack, dan air bersih.

\subsection{Desain Penelitian}

Alur penelitian dimulai dengan penentuan jumlah sampel berpedoman pada rumus deteksi penyakit [15] dengan formula :

$$
\mathrm{n}=\left[1-(1-\mathrm{a})^{1 / \mathrm{D}}\right][\mathrm{N}-(\mathrm{D}-1) / 2]
$$

Jika rata-rata jumlah pemotongan sapi per bulan 417 ekor, asumsi hewan yang sakit $2 \%$ dan tingkat konfidensi 95\%, maka jumlah minimal yang harus diambil adalah 125 ekor sapi. Berdasarkan jumlah tersebut, sebanyak 175 ekor ditetapkan sebagai jumlah sampel yang dianalisis pada penelitian ini untuk memperkecil bias.

Pengambilan sampel darah dilakukan tiap hari (rata-rata 7 sampel/hari) dan pemilihan sapi secara random agar mewakili gambaran kondisi selama 1 bulan. Sampel darah tersebut dibawa ke laboratorium untuk pemisahan serum dan pengujian Rose Bengal Test (RBT) pada hari yang sama.

Prosedur RBT mengacu pada standar OIE [16] dengan tahapan sebagai berikut :

- Pemisahan serum darah dari clot dengan sentrifus berkecepatan $3000 \mathrm{rpm}$ selama 10 menit dan ditempatkan pada suhu ruangan $\left(22^{\circ} \mathrm{C} \pm 4^{\circ} \mathrm{C}\right)$

- Pencampuran serum dan antigen masing-masing sebanyak 25-30 $\mu \mathrm{l}$ ke dalam lempeng porselin dan dihomogenkan selama 1 menit

- Goyang lempeng membentuk angka 8 selama 4 menit

- Serum dinyatakan negatif jika campuran tetap homogen. Serum (+) jika aglutinasi ringan berupa butiran halus dengan tepi membentuk garis putus-putus. Serum (++) jika muncul butiran seperti pasir dengan tepi pinggiran lebar. Serum (+++) butiran terlihat jelas dan kasar.

\subsection{Variabel Penelitian}

Variabel yang diamati pada penelitian ini yaitu hasil RBT, asal sapi, umur, jenis kelamin, dan status kebuntingan.

\subsection{Analisis Data}

Data dianalisis secara deskriptif. Prevalensi reaktor brusellosis diperoleh dari rasio jumlah sampel positif RBT dan jumlah sampel keseluruhan, sedangkan perhitungan rata-rata dan nilai persentase digunakan untuk variabel lainnya. 


\section{Hasil dan Pembahasan}

\subsection{Prevalensi Reaktor Brusellosis}

Prevalensi sapi yang diduga sebagai reaktor brusellosis di RPH Kota Ambon sebanyak 10,29\% (18/175) dengan rincian tingkat aglutinasi 3,43\% (+) dan $6,86 \%(++)$. Hasil ini membuktikan bahwa 18 ekor sapi yang dipotong di RPH memiliki antibodi terhadap brusellosis. Jika diasumsikan sapi-sapi tersebut tidak divaksinasi, maka antibodi yang terdeteksi merupakan hasil paparan dari infeksi alami. Hasil ini perlu divalidasi karena serum yang dinyatakan positif RBT belum tentu positif menggunakan CFT atau uji serologi lainnya. Penggunaan beberapa teknik (complementary test) diperlukan dalam peneguhan diagnosa brucellosis untuk meningkatkan sensitivitas dan spesifisitas uji serologis [16].

Brucella abortus mampu merangsang variasi produksi antibodi dan dipengaruhi oleh sifat antigenitas protein dinding sel agen. Responnya bisa terdeteksi pada minggu 1-2 setelah infeksi [17]. Uji RBT menggambarkan ikatan antigen antibodi di permukaan sehingga cocok dipakai untuk uji tapis (screening test) $[18,19]$.

Revaksinasi menjadi prioritas sehubungan dengan angka prevalensi yang mencapai $10.29 \%$. Langkah ini sesuai dengan kebijakan vaksinasi jika hasil seropositif $>2 \%$ dan pemotongan bersyarat untuk populasi dengan angka prevalensi $<2 \%$. Tahapan pemberantasan brucellosis secara nasional dimulai dengan identifikasi dan penyembelihan semua reaktor, vaksinasi populasi rentan, serta pengendalian lalu lintas dan penelusuran asal ternak. Pada daerah dengan prevalensi tinggi $(>2 \%)$ kegiatan yang dilakukan meliputi peningkatan kesadaran masyarakat, vaksinasi semua sapi betina pada tahun pertama, vaksinasi semua anak sapi betina setiap tahun, pelaporan vaksin yang digunakan, kontrol lalu lintas hewan, pelaksanaan survailans serologis secara berkala, investigasi kasus abortus dengan konfirmasi laboratoris, penelusuran reaktor, dan pengkajian ulang program setiap tahun [20]

Tabel 1. Prevalensi sapi sebagai reaktor brusellosis di RPH Kota Ambon

\begin{tabular}{ccc}
\hline Hasil & $\mathbf{N}$ & $\mathbf{\%}$ \\
\hline$(-)$ & 157 & 89,71 \\
$(+)$ & 6 & 3,43 \\
$(++)$ & 12 & 6,86 \\
$(+++)$ & 0 & 0 \\
\hline Total sampel & 175 & 100 \\
\hline
\end{tabular}

\subsection{Karateristik Sapi Yang Berstatus Reaktor Brucellosis di RPH Kota Ambon}

Tabel 2 menunjukkan bahwa Pulau Seram dan Pulau Buru merupakan pemasok utama kebutuhan daging sapi bagi masyarakat Kota Ambon. Sapi-sapi potong dari Pulau Buru hanya berasal dari satu wilayah, yaitu Kecamatan Namlea. Adapun sapi dari Pulau Seram berasal dari beberapa wilayah antara lain Masohi, Kobisonta, dan beberapa desa di Kecamatan Seram Utara Barat. Pemotongan sapi yang berasal dari Pulau Ambon dan PP Lease ditemukan dalam jumlah sedikit yaitu $9,14 \% \quad(16 / 175)$.

Tabel 2. Karateristik sapi yang berstatus reaktor brucellosis di RPH Kota Ambon

\begin{tabular}{|c|c|c|c|c|c|c|c|}
\hline \multirow{4}{*}{ Variabel } & \multirow{4}{*}{$\begin{array}{l}\text { Jumlah } \\
\text { sampel }\end{array}$} & \multicolumn{6}{|c|}{ Hasil RBT } \\
\hline & & \multicolumn{4}{|c|}{ Positif } & \multirow{2}{*}{\multicolumn{2}{|c|}{ Negatif }} \\
\hline & & \multicolumn{2}{|c|}{+} & \multicolumn{2}{|c|}{++} & & \\
\hline & & $\mathbf{N}$ & $\%$ & $\mathbf{N}$ & $\%$ & $\mathrm{~N}$ & $\%$ \\
\hline \multicolumn{8}{|l|}{ (1) Asal Sapi } \\
\hline - $\quad$ Pulau Seram & 83 & 3 & 3,61 & 7 & 8,44 & 73 & 87,95 \\
\hline - $\quad$ Pulau Buru & 76 & 2 & 2,63 & 6 & 7,90 & 68 & 89,47 \\
\hline - $\quad$ Pulau Ambon PP Lease & 16 & o & o & $\mathrm{o}$ & o & 16 & 100 \\
\hline Total & 175 & \multicolumn{4}{|c|}{$10,29 \%(18 / 175)$} & \multicolumn{2}{|c|}{$89,71 \%(157 / 175)$} \\
\hline \multicolumn{8}{|l|}{ (2) Umur } \\
\hline - $\quad \geq 1,5$ tahun & 132 & 4 & 3,03 & 12 & 9,09 & 116 & 87,88 \\
\hline$-\quad<1,5$ tahun & 43 & 2 & 4,65 & $\mathrm{o}$ & $\mathrm{o}$ & 41 & 95,35 \\
\hline Total & 175 & \multicolumn{4}{|c|}{$10,29 \%(18 / 175)$} & \multicolumn{2}{|c|}{$89,71 \%(157 / 175)$} \\
\hline \multicolumn{8}{|l|}{ (3) Jenis Kelamin } \\
\hline - Betina & 108 & 4 & 3,70 & 8 & 7,41 & 96 & 88,89 \\
\hline - Jantan & 67 & 2 & 2,99 & 4 & 5,97 & 61 & 91,04 \\
\hline Total & 175 & \multicolumn{4}{|c|}{$10,29 \%(18 / 175)$} & \multicolumn{2}{|c|}{$89,71 \%(157 / 175)$} \\
\hline \multicolumn{8}{|l|}{ (4) Status Kebuntingan* } \\
\hline - Bunting & 55 & 1 & 1,82 & 8 & 14,54 & 46 & 83,64 \\
\hline - $\quad$ Tidak bunting & 53 & 1 & 1,89 & 2 & 3,77 & 50 & 94,34 \\
\hline Total & 108 & & 11,1 & 108 & & & $/ 108)$ \\
\hline
\end{tabular}

Hasil pemeriksaan RBT menunjukkan secara keseluruhan reaktor brucellosis asal Pulau Seram sebanyak 5,71\% (10/175) dan Pulau Buru 4,57\% $(8 / 175)$. Jika dirinci berdasarkan hasil RBT terlihat bahwa reaktor dengan derajat aglutinasi $(++)$ jumlahnya 2 kali lebih tinggi dengan persentase tertinggi ditemukan di Pulau Seram.

Pulau Seram dan Pulau Buru merupakan sentra pengembangan ternak ruminansia di Provinsi Maluku. Walaupun secara umum 
peternaknya masih mengadopsi pola tradisional, namun manajemen pemeliharaan kedua daerah tersebut berbeda. Peternak di Pulau Seram bertumpu pada sistem lepas-ikat di padang penggembalaan sementara peternak di Pulau Buru (khususnya daerah transmigrasi) memiliki kandang untuk memudahkan pengawasan. Perbedaan ini secara tidak langsung mempengaruhi laju penyebaran brusellosis yang dengan mudah dapat mengkontaminasi rumput lapangan melalui sisasisa abortus atau cairan vaginal. Hasil ini mempertegas laporan investigasi tim Balai Besar Veteriner (BBV) Maros pada tahun 2017 tentang kecenderungan temuan reaktor pada populasi sapi asal dari Pulau Seram.

Sapi yang dipotong di RPH Kota Ambon didominasi oleh kategori umur 1,5-3 tahun (69,14\%). Kelompok sapi berumur < 1,5 tahun menempati urutan kedua dengan persentase 24,57\%. Pemotongan sapi berumur 3-5 tahun dan $>5$ tahun berturut-turut 5,71\% dan o,57 (Gambar 1). Angka ini menunjukkan bahwa sapi-sapi yang dipotong di $\mathrm{RPH}$ berada pada masa produktif atau sudah mencapai dewasa kelamin.

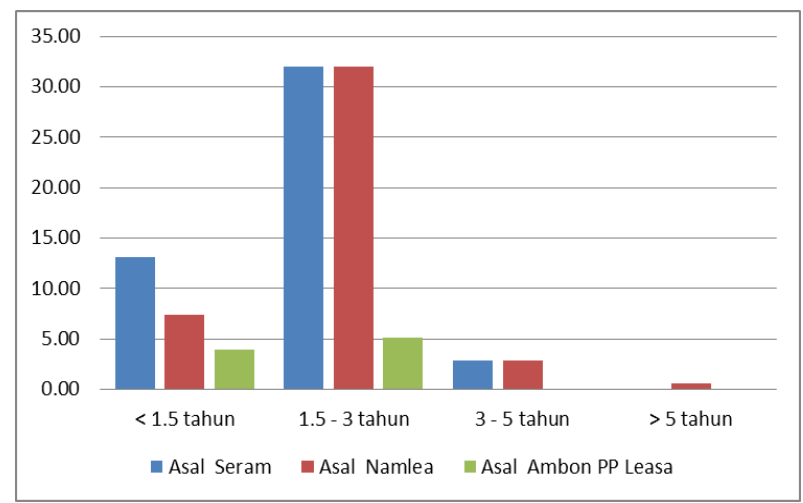

Gambar 1. Umur sapi yang dipotong di RPH Kota Ambon

Dewasa kelamin merupakan salah satu faktor predisposisi dalam infeksi brucellosis. Sapi yang sudah mencapai dewasa kelamin akan lebih banyak memproduksi eritritol, yaitu senyawa kimia yang digunakan oleh agen (Brucella spp) untuk bertahan hidup [21]. Adanya peningkatan konsentrasi eritritol dan hormon seksual turut merangsang multipikasi agen penyebab, artinya ada korelasi antara umur dan kerentanan terhadap infeksi brusellosis. Sapi yang terinfeksi setelah mencapai dewasa kelamin lebih beresiko memunculkan gejala klinis dan berpotensi menjadi karrier [22].

Persentase sapi betina yang dipotong lebih tinggi daripada sapi jantan, yaitu mencapai $61,71 \%$ (108/175). Jika dikategorikan berdasarkan umur terlihat pemotongan terjadi pada kisaran umur 1,5-3 tahun dengan persentase $44 \%(77 / 175)$ sapi betina dan 25,71\% (45/175) sapi jantan (Gambar 2). Tingginya tingkat pemotongan betina produktif turut dipicu perbedaan harga signifikan antara sapi jantan dan betina di pasaran sehingga para pedagang cenderung mempengaruhi peternak untuk menjual sapi betina walaupun masih berada pada usia produktif [23].

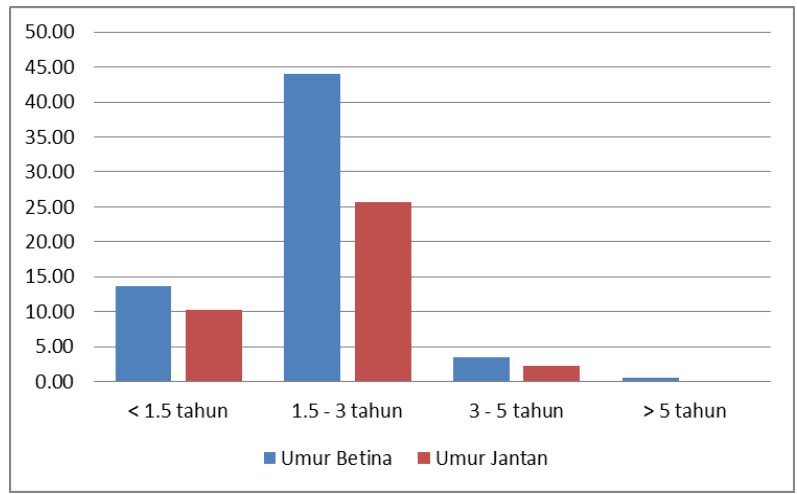

Gambar 2. Distribusi jenis kelamin sapi yang dipotong di RPH Kota Ambon berdasarkan umur

Persentase sapi betina yang memiliki titer antibodi terhadap brucellosis mencapai $11,11 \%$ (12/108), dengan rincian 3,70\% (4/108) memiliki tingkat aglutinasi (+) dan 7,41\% (8/108) aglutinasi $(++)$. Sapi betina sebagai reaktor brusellosis 2 kali lebih tinggi dibandingkan sapi jantan. Hasil ini juga dilaporkan oleh beberapa peneliti terdahulu, misalnya temuan di Pulau Jawa [24] maupun di Kupang [25]. Sapi betina dewasa memproduksi eritritol dalam jumlah berlimpah di uterus dan jaringan fetus, yaitu plasenta, chorio alantois, dan air ketuban [26]. Selain itu, sumber utama penularan pada sapi betina dapat berasal dari kolostrum.

Persentase sapi betina bunting yang dipotong mencapai 50,93\% (55/108) menjadi temuan serius. Data ini menunjukkan lemahnya inspeksi di tingkat RPH, minimnya kesadaran peternak untuk mencegah penjualan betina produktif, dan faktor penghambat program swasembada daging sapi di Provinsi Maluku. Sejumlah 16,36\% (9/55) sapi betina bunting memiliki titer antibodi terhadap brucellosis dengan persentase tertinggi pada tingkat aglutinasi $(++)$ yaitu $14,54 \%(8 / 55)$

Status kebuntingan juga berasosiasi dengan produksi eritritol. Tingginya produksi eritritol juga menjadi indikator derajat infeksi bakteri di saluran reproduksi dan merangsang masifnya produksi antibodi di saluran reproduksi. Koloni bakteri pada vili, ruang di antara vili, dan membran plasenta memicu peradangan pada dinding uterus dan plasenta serta menghalangi transportasi nutrisi dari induk ke fetus. Rapuhnya tautan tersebut memicu keguguran. Umumnya infeksi kronis dialami oleh induk yang sudah mengalami 2-3 kali keguguran, namun tidak selalu diikuti oleh gejala klinis dan berpeluang bunting kembali [27]. Kelompok sapi ini 
tergolong sebagai pembawa penyakit (karrier) dan menjadi sumber penular bagi ternak lain.

Berdasarkan berbagai temuan di atas diperlukan tanggap cepat untuk mengevaluasi status reaktor brusellosis pada populasi sapi di RPH Kota Ambon. Hasil uji RBT segera divalidasi dengan uji CFT untuk memperkuat penegakan diagnosa brusellosis. Langkah ini dipandang mendesak mengingat potensi penularan penyakit ini ke para penjagal (zoonosis). Selain itu, penjualan organ visceral termasuk saluran reproduksi ke berbagai warung makan semakin memperbesar resiko penularan ke manusia. Hasil pengujian tersebut sekaligus menggambarkan status infeksi di daerah asal ternak sehingga dinas terkait dapat menentukan langkah pengendalian selanjutnya.

\section{Kesimpulan}

Reaktor brusellosis terdeteksi pada sapi-sapi yang dipotong di RPH Kota Ambon (10,29\%) yang terdiri dari $5,71 \%$ berasal dari Pulau Seram dan 4,57\% dari Pulau Buru berdasarkan uji RBT.

\section{Referensi}

[1] FAO, Transforming the Livestock Sector Through The Sustainable Development Goals. Rome : FAO Press, 2018.

[2] FAO, Guidelines for Coordinated Human and Animal Brucellosis Surveillance. Rome : FAO Press, 2003.

[3] C. Basri and B. Sumiarto, "Taksiran Kerugian Ekonomi Penyakit Kluron Menular (Brucellosis) pada Populasi Ternak di Indonesia", JURNAL VETERINER, vol. 18, no. 4, pp. 547-556, December 2017.

[4] Madiha, "Brucellosis General Information", 2011. [Online]. Available: http://www.humenhealth.com. [14 Juli 2020].

[5] B.B. Singh, N.K. Dhand, and J.PS. Gill, "Economic Losses Occuring Due To Brucellosis in Indian Livestock Populations", PREVENTIVE VETERINARY MEDICINE, vol. 119, no. 3, pp. 211-215, May 2015.

[6] M. Geong, "The Epidemiology of Bovne Brucellosis in Timor - Indonesia", Murdoch University, 1999. (Dissertation).

[7] T.A. Ulfah and Haryono, "Studi Kejadian Brucellosis di Maluku", PROSIDING SEMINAR NASIONAL PETERNAKAN DAN VETERINER, pp. 958-962, 1998.

[8] Dinas Pertanian Provinsi Maluku, Laporan Tahunan Penyakit Hewan Menular. Ambon : Distanprov, 2013.

[9] B.B. Lekioy, "Identifikasi Penyakit Brucellosis Pada Ternak Sapi di Kecamatan Leti,
Kabupaten Maluku Barat Daya”, Universitas Pattimura, 2017. (Skripsi).

[10] Arsyalini, "Seroprevalensi Brusellosis pada Sapi di Rumah Potong Hewan Tamangapa Kota Makasar", Universitas Hasanudin, 2014. (Skripsi).

[11] E. Rohyati, N.N. Toelle, and E.R. Hau, "Uji Tapis Brusellosis Pada Sapi di RPH Oeba Kota Kupang Dengan Menggunakan Uji RBT", PATNER, vol. 23, no.2, pp. 705-709, November 2018.

[12] I. Nabukenya, D. Kaddu-mulindwa, and G.W. Nasinyama, "Survey of Brucella Infection and Malaria Among Abattoir Workers in Kampala and Mbarara Districts, Uganda", BMC PUBLIC Health, vol. 13, no. 1, pp. 2-6, September 2013.

[13] Nasinyama, G.W, E. Sskawojwa, J. Opuda, P. Grimaud, E. Etter, and Z. Bellinguez, "Brucella Sero-prevalence and Modifiable Risk Factors Among Predisposed Cattle Keepers and Consumers of Un-pasteurized Milk in Mbarara and Kampala District, Uganda", AFR HEALTH SCIENCE, vol. 14, no. 4, pp. 2-5, Desember 2014.

[14] Direktorat Jenderal Peternakan (Ditjeknak), "Statistik Peternakan dan Kesehatan Hewan" 2017. [Online]. Available : http://ditjenak.pertanian.go.id. [30 Juni 2020].

[15] S.W. Marthin, A.H. Meek, A.H. Wilberg, Veterinary Epidemiology. Iowa : Iowa State University Press, 1987.

[16] Office International des Epizooties (OIE), Manual of Diagnostic Tests and Vaccines for Terrestrial Animal (mammals, birds, and bees) - Eight Edition. Paris : OIE, 2018.

[17] M.M. Megid, L.A. Mathias, and C.A. Robles, "Clinical Manifestations of Brucellosis in Domestic Animal and Human", THE OPEN VETERINARY SCIENCE JOURNAL, vol. 4, no. 1, pp. 119-126, May 2010.

[18] A.K. Dewi, "Kajian Brucellosis pada Sapi dan Kambing Potong yang Dilalulintaskan di Penyeberangan Merak, Banten", Institut Pertanian Bogor, 2009. (Tesis).

[19] I.W. Batan, Sapi Bali dan Penyakitnya. Denpasar: Fakultas Kedokteran Hewan Universitas Udayana, 2006.

[20] Direktorat Jenderal Peternakan (Ditjeknak), Road Map Pengendalian dan Penanggulangan Brucellosis. [Online]. Available : http://civas.net/cms/assets/uploads/2019/og. [30 Juni 2020].

[21] H. Dinka and R. Chala, "Seroprevalence Study of Bovine Brucellosis in Pastoral and AgroPastoral Areas of East Showa Zone, Oromia Regional State, Ethiopia", AMERICANEURASIAN J OF AGRIC ENVIRON SCI. vol. 6, no. 5, pp. 508-512, Januari 2009. 
[22] Soeharsono, Penyakit Menular dari Hewan ke Manusia. Yogyakarta : Penerbit Kanisius, 2002.

[23] S.M. Noor, "Epidemiologi dan Pengendalian Brusellosis Pada Sapi Perah di Pulau Jawa. 2006. [Online]. Available : http://balitnak.litbang.pertanian.go.id [23 Juli 2020].

[24] S. Pesulima, "Tingkat Insidensi Pemotongan Sapi Betina Produktif di Rumah Potong Hewan Kota Ambon", Universitas Pattimura, 2019. (Skripsi).

[25] . Perwitasari, "Prevalensi dan Faktor Penyebab Brusellosis pada Sapi Potong di Kabupaten Kupang", Universitas Gadjah Mada, 2010. (Tesis).

[26] E. Petersen, G. Rajashekara, N. Sanakkayala, and L. Eskra, "Erythritol Triggers Expression of Virulence Traits in Brucella melitensis", MICROBES AND INFECTION. Vol. 5, no. 6, pp. 440-449, February 2013.

[27] F.P. Poester, L.E. Samartino, and R.L. Santos, "Pathogenesis and Pathobiology of Brucellosis in Livestock", REV SCIE. TECH OFF INT EPIZ, vol. 32, no. 1, pp. 105-115, April 2013. 